\title{
河川工事を対象とした設計・施工段階に おける環境負荷低減方策の検討
}

\author{
池田 鉄哉 1 ・天野 邦彦 2 岸田 弘之 3 \\ 1正会員 社団法人国際建設技術協会＼cjkstart研究第2部長 \\ （干102-0083 東京都千代田区丧町5-3-23） \\ (前)国土交通省国土技術政策総合研究所 環境研究部河川環境研究室 \\ E-mail:ttyikeda@hotmail.com \\ 2正会員 国土交通省国土技術政策総合研究所 環境研究部河川環境研究室長 \\ E-mail:amano-k92ta@nilim.go.jp \\ 3フェロー会員 国土交通省国土技術政策総合研究所 研究総務官 \\ (前)国土交通省国土技術政策総合研究所 環境研究部長
}

E-mail:kishida-h2rq@nilim.go.jp

\begin{abstract}
河川工事などの社会資本整備分野では，コンクリートなど多くの資材を使用し，またその運搬距離も長 くなる. 昨今の環境問題に対する国民意識の高まりから, 社会資本整備による環境負荷量を算定し, その 低減に向けた取り組みが重要となってきている．社会資本整備分野では広域的・長期的な環境負荷として 二酸化炭素 $\left(\mathrm{CO}_{2}\right)$ の排出や廃衰物の発生に留意が必要であるが, これら環境負荷量については実際の事 業の実施状況を踏まえて定量的に評価し，その低減方策の検討が必要である。本稿は実際の河川工事を対 象として，まずは設計段階において複数の代替案に係るコスト及び $\mathrm{CO}_{2}$ 排出量等を算定するとともに, LIME2の統合化指標を用いた比較検討を行い，環境負荷低減効果の分析を行った。また施工段階について 環境負荷低減に関するシナリオ設定を行い，資材を新たに採取・製造する標準案（ベースラインシナリ オ）に対する環境負荷低減効果の分析を行った。さらに本検討を踏まえ，全国の河川管理者や建設コンサ ルタント・施工会社が参照できるような環境負荷低減を意図した河道設計・施工の検討手順を構築した。
\end{abstract}

Key Words : river embankment and revetment work, $\mathrm{CO}_{2}$ emission volume, construction waste reduction scenario of environmental load, LIME2

\section{1. はじめに}

河川工事や道路工事などの社会資本整備分野では，土 砂やコンクリートなど多くの資材を使用するとともに， その運搬距離も長くなることで多くのエネルギーを消費 する. また工事の実施に伴い既設の構造物を取り壊し処 分することで廃棄物を発生させる.これまで河川工事等 では資材使用量やエネルギー消費量の削減，コストの縮 減, 廃棄物の再利用などの取り組みが既に進められてき たものの，二酸化炭素 $\left(\mathrm{CO}_{2}\right)$ 排出量や廃棄物発生量な ど河川工事等による環境負荷の低減に関する全体的な評 価手法が確立されるまでには至っていない.

一方で, 地球温暖化など昨今の環境問題に対する国民
意識の高まりや廃棄物の発生抑制, 資源の持続可能な利 用を図る必要性から, 社会資本整備による環境負荷量を 算定し，その低減に向けた取り組みが重要となってきて いる. 水質污濁や大気污染などの局所的な環境影響以外 で，広域的・長期的な環境負荷としては $\mathrm{CO}_{2}$ や残土・廃 棄物，そしてオゾン層破壊をもたらすフロン類や人間・ 生態毒性を有する金属類等があげられる. 一般的な河川 工事ではフロン類や金属類の排出は考えにくいことから， まずは $\mathrm{CO}_{2}$ の排出や残土・廃葉物の発生に留意が必要と なる，そしてこれらの環境負荷については，実際の事業 の実施状況を踏まえて定量的に評価し，資材の再利用等 による低減方策の検討が必要である．このとき事業の設 計・施工の各段階では, 取り扱う情報の種類や精度が異 
なるため，各段階で入手可能な情報に基づいて評価を行 う必要がある。一般的に設計段階においては改修平面や 横断形状，そして洪水を安全に流下させるために必要な 護岸の性能やタイプ等が検討される．これに対し，施工 段階では例えば護岸等について, 必要な性能が確保され る範囲で, どのような商品をどのように調達すべきか, また工事によって発生する残土や廃棄物をどのように処 理又は再利用するかについて検討が行われる，また設計 段階と施工段階とでは例えば設計は建設コンサルタント が実施し，それを受けて施工会社が工事を実施する。そ して発注者の側でも設計・施工担当部局が分かれている 場合がある。このため設計から施工までの全体の流れの 中で各段階での環境負荷量を算定し，その低減方策を検 討するための手順を構築することが求められる.

これまで河川の築堤・護岸工事による $\mathrm{CO}_{2}$ 排出量につ いては島谷ら(1998) $)^{1}$ ，池田ら(2010) ${ }^{2}$ ，山田ら $(2010)^{3)}$ によ って試算・算定が行われてきたが，いずれも設計段階に 留まり，設計・施工それぞれの段階で取り扱う情報の相 違を考慮したものとなっていない．また今後河川工事等 に対して環境負荷低減方策を適用しようとする場合は, より実態に即した検討を重ねることによってその手法を 確立させることが必要である.さらにこれまでの研究は $\mathrm{CO}_{2}$ 排出量だけを取り扱うものであり, 廃棄物発生量な どCO $\mathrm{C}_{2}$ 排出量以外の環境負荷やその再利用までを考慮し たものとはなっていない，このため本稿では，実際の河 川事業を対象として, 設計段階において複数の河道己㤵修 案を想定し, 各案の事業費や用地面積, 工事を行う際に 排出される $\mathrm{CO}_{2}$ 排出量や廃棄物発生量を算定した。 また 異なる環境負荷を共通の指標によって評価するため, 現 在提案されているLIME2（日本版被害算定型影響評価手 法第2期プロジェクト）の統合化係数を用いて比較検討 を行った. そして施工段階では土砂や資材の再利用など によって環境負荷の低減が期待されることから，そのよ うな低減方策を講じた場合の環境負荷について，資材を 新たに採取・製造する標準案 (ベースラインシナリオ) に係る環境負荷との比較を行い, 低減効果を分析した. さらにこのような環境負荷量の算定及び低減方策の検討 を踏まえ，これまで適用されてきた河道設計・施工の流 れに対し，全国の河川管理者や建設コンサルタント・施 工会社が参照できるような環境負荷低減を意図した河道 設計・施工の検討手順を構築した.

\section{2. 設計段階での環境負荷低減方策の検討}

実際に河川改修工事を行おうとする段階では，改修平 面・横断形状などが既に確定している場合が多いことか ら，それらを大幅に変更できる余地が少なく，そこでの
環境負荷低減方策も自ずと限定的となってしまう。この ため設計から施工までの全体の流れの中で環境負荷の低 減を図るためには，まず設計段階で河道の平面・横断形 状の変更などの工夫により環境負荷がどの程度低減でき るかを検討する必要がある。ここでは河道の全面改修が 予定され，現時点で設計図書等が入手可能な都市近郊を 流れる中小河川（流域面積 $12.4 \mathrm{~km}^{2}$ ）を検討対象とした。

この改修事業は，既設護岸を撤去して河道の両岸拡幅 (約 $6 \mathrm{~m} \rightarrow 8 \sim 9 \mathrm{~m})$ を行って現況の流下能力（25 $60 \mathrm{~m}^{3} / \mathrm{s}$ 程度) に対して計画高水流量 $80 \mathrm{~m}^{3} / \mathrm{s}$ を流下させる断面に まで拡大し，50年確率降雨に対する治水安全度を確保し ようとするものである. 改修の当初計画は全区間にわた って用地を買収して両岸拡幅及び河床掘削を行い, 河岸 法勾配1:0.5の石積護岸を整備するものである. この当初 計画に対して, 計画高水流量を安全に流下させることを

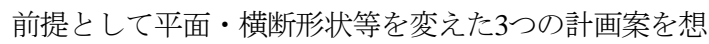
定した. そして各案について想定する平面図・横断図を 用いて必要となる護岸等の資材使用量や土砂掘削量等を 算出するとともに, 事業費や $\mathrm{CO}_{2}$ 排出量 - 廃棄物発生量 といった環境負荷量を算定した，そして異なる環境負荷 を共通の指標によって評価すべく，LIME2の統合化係数 を用いて比較検討を行うとともに各案の環境負荷低減効 果を分析し，その実現可能性を考察した.

検討対象とする環境負荷のうち $\mathrm{CO}_{2}$ 排出量については, 池田ら(2010)が河川の築堤・護岸工事に対して実施した 試算手法を踏襲した。 これにより河川改修で必要となる 建設機械の製造及び稼動段階, 資材の製造及び運搬段階 での $\mathrm{CO}_{2}$ 排出量をそれぞれ算定した。 ここで $\mathrm{CO}_{2}$ 排出量 の原単位は「産業連関表による環境負荷原単位データブ ック（3EID）」 ${ }^{4} に$ 示されている生産者価格当たりの $\mathrm{CO}_{2}$ 排出量原単位（t-CO $/$ 百万円）と産業連関表の部門別 品目別国内生産額表の品目別単価を用いることとした. その他建設機械の稼動段階での施工能力や資材の運搬段 階でのダンプトラックの燃費, 時速等は国土交通省が行 う工事に適用される標準的な数值を用いることとした. また土砂・資材の調達先及び残土・廃棄物の処分先に関 しては, 当該工事が行われる県庁所在地とした（ここで は9.5kmとした）。

代替案の設定について，全区間にわたって両岸拡幅を 行う当初計画に対し, 用地取得及び家屋移転を極力抑え るべく, 現況の川幅をなるべく拡げないよう護岸を直立 させて河床掘削を行うものを代替案(i)とした．代替案(i) では当初計画に対して掘削土量を低減できることから残 土処理に伴う環境負荷の低減が期待される．また既設護 岸を最大限利用して両岸拡幅ではなく片岸のみを拡幅す るものを代替案(ii)とした。代替案(ii)は片方の河岸にの み護岸を設置するため, 護岸を両岸に設置する当初計画 に対して護岸の製造段階における $\mathrm{CO}_{2}$ 排出量の低減が期 
待される. 当初計画及び代替案(i)〜(ii)の平面形状のイメ ージと横断形状を図-1に示寸，その他の代替案として， 河川環境への配慮及びコンクリートの使用抑制を図るべ く河岸法勾配1:2.0の土堤とする案も考えられる.これは 護岸を使用しないため，護岸を設置する当初計画に対し て護岸の製造段階における $\mathrm{CO}_{2}$ 排出量の低減が期待され るが，河岸法勾配を1:2.0とすることで掘削土量が増加し， その処理に伴う環境負荷が増大寸ることも予想される. 本案については，国土交通省が策定した中小河川の技術 基準 りに照らしてその適用可能性を検討した. 同基準で は用地幅の制約がある場合は法勾配を5分程度として河 床幅を十分に確保寸ることが有効としている．また河岸 防御を行う必要性が低い場合や改修後の代表流速が $1.8 \mathrm{~m} / \mathrm{s}$ 以下の箇所等では護岸を設置しないことを原則と している.ここで本河川の法勾配を1:2.0とした場合，用 地取得・家屋補償が多大になり，またそのことで十分な

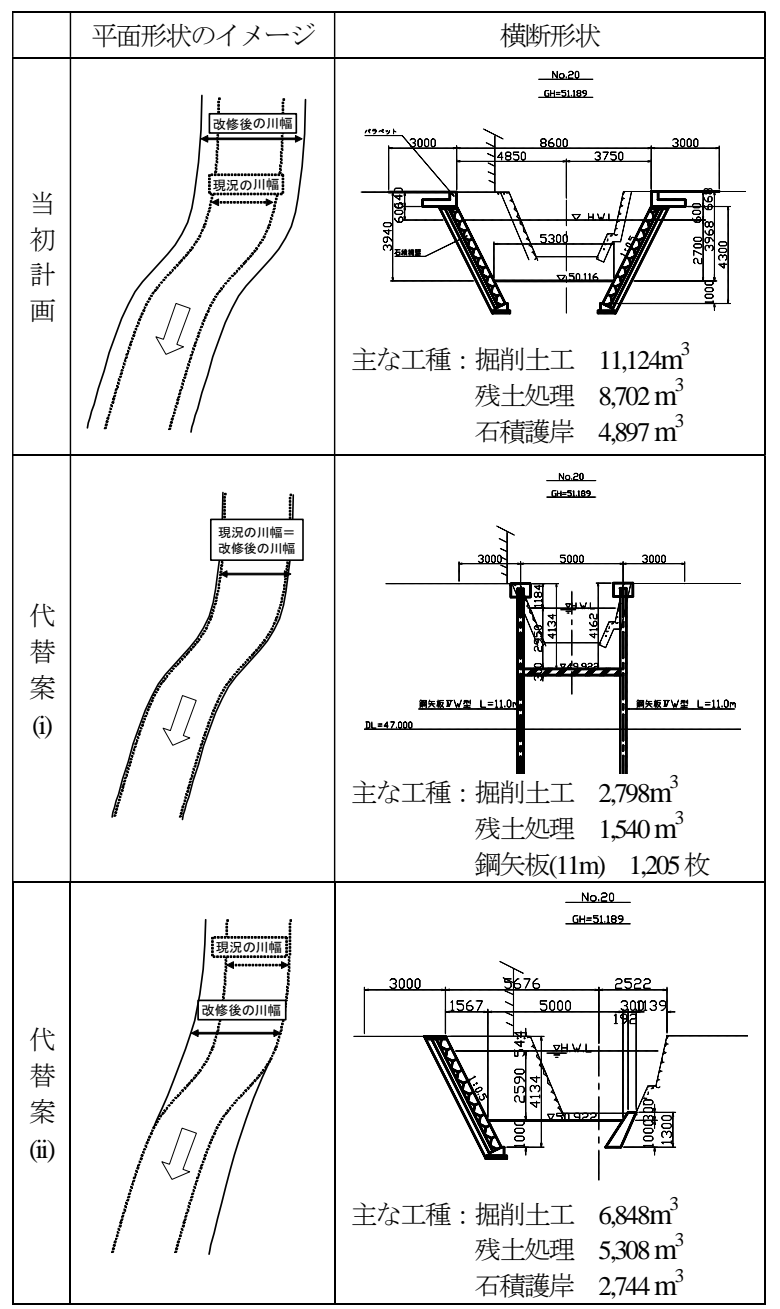

図-1 検討対象河川の改修当初計画及び代替案(i) (ii)の 平面形状のイメージと横断形状
河床幅が確保できなくなる，そして本河川の河床縦断勾 配は 1/80～1/100 と比較的急であり，改修後の流速は $4 \mathrm{~m} / \mathrm{s}$ を超えると予想されることから，護岸を設けなければ河 岸侵食が生じるおそれがある.このため代替案として法 勾配1:2.0の土堤による改修案を考慮しないこととした.

これにより当初計画及び代替案(i) (ii)に係る事業費と 環境負荷量を算定し，その環境負荷量に関して LIME2 による統合化係数のを用いて比較した結果を表-1 に示す。 この結果, 代替案(i)では事業費が代替案(ii)の約 1.5 倍と なったものの，廃棄物を含めた被害額が最も少なかった， これは鋼矢板を用いたため, 事業費, $\mathrm{CO}_{2}$ 排出量とも多 くなったものの，残土の発生が少なかったためであった. また事業費と $\mathrm{CO}_{2}$ 排出量のみ考慮した場合は代替案(ii)が 有利となった。この代替案(ii)は，両岸改修を行う当初 計画に対して既設護岸を利用する片岸改修であるため, 事業費 $\cdot \mathrm{CO}_{2}$ 排出量とも半分近くにまで低減された.

ここで代替案(i)及び(ii)の適用可能性について考察する。 代替案(i)では全体の被害額が最も小さかったものの, 事 業費が高く, そして三面張り水路となってしまうため生 態系・景観の面で問題が多い。また代替案(ii)では全体 の被害額が代替案(i)よりも多く，その原因は残土の発生 によるものであった．しかしながら残土や廃款等に関し ては，他の工事との間で再利用を行うことが可能であり， 工事の実施に際して残土の受け入れ先が確保できればそ の分被害額を低減することができて，結果的に当初計画， 代替案(i)よりも有利となることも想定される. ただし代 替案(ii)では既設護岸の耐久性が疑問視されること, ま た片側の既設護岸に根入れを行うこととしているが，構 造的・強度的な問題が生じないかどうか，そして片岸だ けを拡幅して改修することに地元住民の賛同が得られる かなどの課題も考えられる.このため河道改修案の決定 に当たっては，既設護岸の耐久性の確認や受益者であり 用地提供者である地元住民の意見を踏まえて慎重に行う 必要がある.

表-1 当初計画及び代替案(i)〜(ii)による事業費と被害額の比較

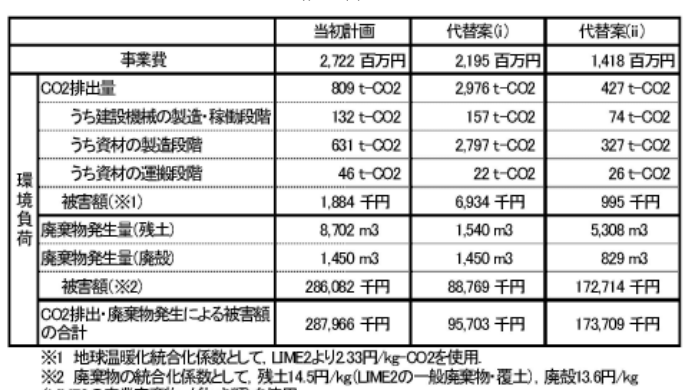

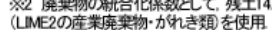




\section{3. 施工段階での環境負荷低減方策の検討}

\section{（1）環境負荷低減シナリオの設定の考え方}

河川工事などの社会資本整備では，土砂やコンクリー 卜など多くの資材を採取・調達し，また工事から発生す る残土や廃款などの不要物を処理することによって環境 負荷が発生寸る，そして資材を運搬，不要物を処分場ま で搬出させることによってもダンプトラックなどの燃料 消費に伴い $\mathrm{CO}_{2}$ の排出といった環境負荷が生じることと なる. これまでの試算結果から, 多くの土砂・コンクリ 一トを使用する河川工事ではブロック護岸など資材の製 造段階での $\mathrm{CO}_{2}$ 排出量の割合が大きく，そこでの取り組 みが排出量低減に効果的である.このため, 検討対象と する河川工事以外の他の工事から残土・廃殼を調達・再 利用することやリサイクル材を用いることなどによって, 環境負荷の大幅な低減が期待される.ここでは河川工事 について, 土砂の再利用などによって環境負荷低減を図 るシナリオの設定を行う. なお河川工事終了後の維持管 理は，堤防の除草や定期的な点検行為であり，これらに よる環境負荷は工事実施による環境負荷に比べてわずか と考えられる.このため, ここでは維持管理による環境 負荷は検討対象としないこととした.

まずは検討対象とする河川工事（Y工事）について， 他の工事との間で資材の再利用を行わないケースを図-2 上段に示寸標準案（ベースラインシナリオ）と考える. ここでは工事に必要な資材を新たに採取・製造して運搬 するとともに, 工事から発生する不要物（残土や廃棄 物）を搬出して処理を行うこととし，それら新材（バー ジン材）の製造・運搬及び不要物の搬出・処理といった 工程を境界 (バウンダリー) に含めて, $\mathrm{CO}_{2}$ 排出量など の環境負荷を算定する.

これに対し，今日の社会資本整備では資源の有効利用

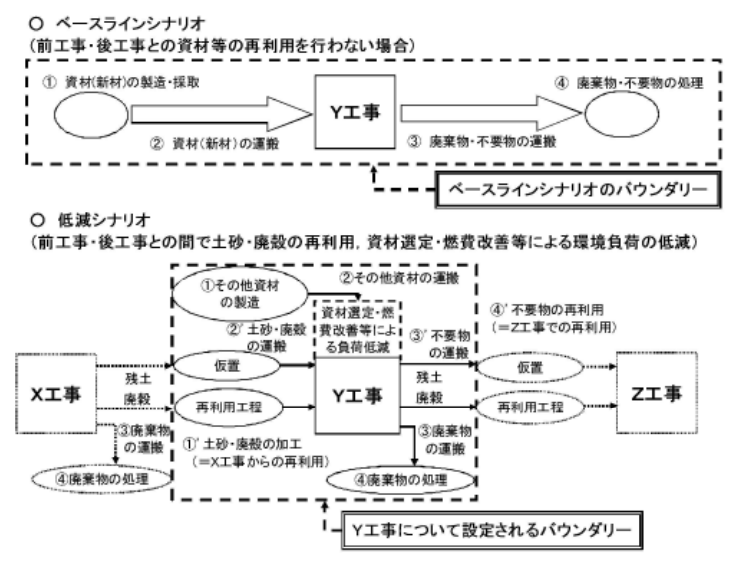

図-2 ベースラインシナリオと低減シナリオの設定と そのバウンダリーの考え方
や廃棄物の発生抑制, 自然環境・生態系への配慮といっ た観点から，当該工事に必要な資材は他の工事で発生し た残土や廃殼を再利用するとともに，当該工事で発生す る不要物に関しても後の工事一転用・リサイクルするこ とで循環利用しようとする動きが進められている．この ような動向を踏まえ, Y工事に必要な土砂や廃款を前の 工事 (X工事) から調達して再利用し，またその他の資 材としてリサイクル材を用いることなどにより環境負荷 低減に取り組むケースを低減シナリオとして図-2下段に 示寸.この低減シナリオは, 資材を新たに採取・製造し て残土や廃棄物を処理するべースラインシナリオに対し， 前のX工事で発生した不要物については, 例えば残土で あればストックヤードを確保して仮置きし，またコンク リート塊などの廃凯はリサイクル工場に持ち込み, Y工 事で再利用しようとするものである.このため，Y工事 の側から寸ればX工事からの不要物を再利用（低減シナ リオ・Y工事における(1)〜(2)’の工程) するため, 資材 の製造・運搬段階（Y工事における(1)～(2)の工程）での 環境負荷を低減させることができる．またX工事からの 不要物をそのまま再利用できない場合も想定されること から, (1)の再生材の加工に伴う環境負荷はY工事のバウ ンダリーに含めて考える.このときX工事の側としても, 不要物がY工事で再利用され, その運搬・処理工程 $(X$ 工事における(3)～(4)の工程) からの環境負荷を低減させ たこととなる．同様にY工事の側としても残土や廃款を その後のZ工事で再利用させることで, (3)～(4)の運搬・ 処理による環境負荷が低減される，このように前の工事 からの不要物を再利用し，そして当該工事からの不要物 を後の工事で再利用させることで資材の製造・運搬及び 廃棄物の搬出・処理工程での環境負荷低減が可能となり, 加えて建設機械の稼働段階での燃費改善等によって更な る環境負荷の低減も期待される．ただしこのように土砂 等を再利用しようとする場合, 再利用先までの運搬距離 が新材の調達元又は処分場までの運搬距離より長くなれ ば, その分環境負荷低減効果が小さくなってしまう。こ のため, 工事実施に先立つ設計の段階から，近隣で再利 用可能な資材が発生するような工事や，当該工事から発 生する不要物を受け入れてもらえそうな工事を早期に探 し出し, 受け取り・受け入れに関するスケジュール等の 調整を進めておくことが重要となる.

以上の考え方により, ベースラインシナリオに対して 設定した低減シナリオによる環境負荷低減のイメージを 図-3に示す。ここでX工事で発生した残土や廃款をY工 事で再利用し，加えてY工事で発生した残土等はZ工事 で再利用しようとするものを低減シナリオ I とする. ま た低減シナリオ IIでは, 低減シナリオ I での取り組みに 加えて, 土砂・廃殼以外で護岸や根固といった資材の選 定の工夫やリサイクル材の使用, 建設機械の稼働段階で 


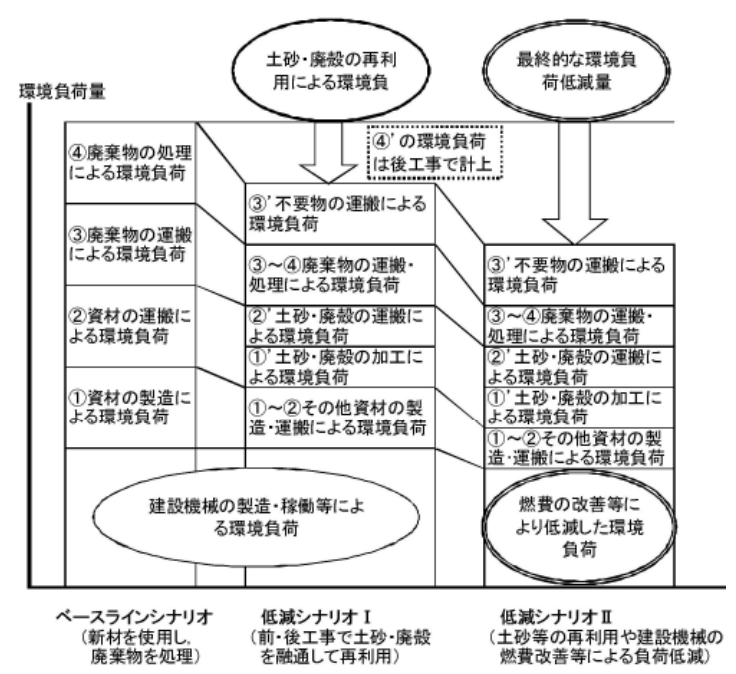

図-3 ベースラインシナリオに対する各低減シナリオにおける 環境負荷低減のイメージ

の燃費改善等によって更なる環境負荷低減に取り組むも のとする.

\section{（2）実際に施エされている河川工事を対象とした低減 方策の検討}

ここでは実際に施工されている河川工事を対象として, ベースラインシナリオに対し各低減シナリオでの環境負 荷低減方策について検討を行う。対象工事は，工事に関 する情報が比較的多いことから，池田ら(2010)が試算を 行ったA河川の築堤・護岸工事とした.

$\mathrm{A}$ 河川の築堤・護岸工事に必要な土砂は，同河川で過 年度実施された掘削工事による残土が再利用されている。 そして工事で発生した残土は区域内に仮置きして他の工 事で再利用される予定であるが，ここで設定するベース ラインシナリオでは必要な資材はすべて新材によるもの とし, 残土や廃殼は寸べて処分場に運搬して処理される ものとした. このとき土砂の調達先及び残土の処分先は 当該工事が行われる県庁所在地とした.

次に低減シナリオ I では, 複数の工事間での調整・や り取りを行うことによって, 他の工事で発生する残土や コンクリート・アスファルト等の廃款をすべて再利用す ることとし，そして当該工事で発生する残上・廃款につ いても別の工事で再利用されるものとした.

このような残上・廃款を再利用する低減シナリオ I で の方策に加え, 低減シナリオ II では護岸や根固といった 資材の選定の工夫やリサイクル材の使用等によって環境 負荷を低減させることとした。 なお低減シナリオ I 及び IIに係る環境負荷としては，いずれも廃杗物は発生しな いため $\mathrm{CO}_{2}$ 排出量のみを対象とした.
A河川の築堤・護岸工事では, 築堤盛土に必要な土砂 以外に護岸・根固として多くのコンクリート・ブロック 製品が使用される. 設計段階では護岸の性能やタイプ等 が検討されるのに対し, 施工段階では護岸等に関してど のような商品を選定すべきかなどの検討が行われる.こ のため護岸等の選定に際して, 所定の性能を満たす範囲 で複数の候補から特定の製品を選定することで，その製 造段階における $\mathrm{CO}_{2}$ 排出量を低減できる可能性がある. 今日, 多くのメーカーが様々な護岸・根固ブロック製品 を製造・販売しており, 同じ性能が確保される場合であ っても，各製品で使用される材料（コンクリートや鉄筋 等）によって各製品単位での $\mathrm{CO}_{2}$ 排出量が異なる可能性 があり，それら異なる製品によって $\mathrm{CO}_{2}$ 排出量がどの程 度変化するかを調查した. 具体的には現在, 市販されて

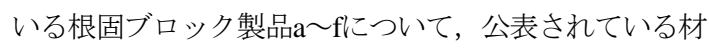

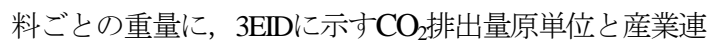
関表の部門別品目別国内生産額表の品目別単価を乗じて $\mathrm{CO}_{2}$ 排出量をそれぞれ算定した. 調査対象とした根固ブ ロック製品の例を図-4に，各製品（1 1 型）の材料構成を 表-2に，そしてそれらの製造段階における $\mathrm{CO}_{2}$ 排出量の 算定結果を図-5に示寸．これにより異なる製品の製造段
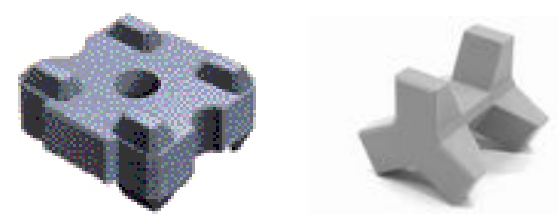

図-4 異なる根固ブロック製品の例 7,8$)$

表-2 各根固ブロック製品（1t型）の材料構成

\begin{tabular}{|c|c|c|c|c|c|c|}
\hline & 製品a & 製品b & 製品c & 製品d & 製品e & 製品f \\
\hline $\begin{array}{l}\text { コンクリート・ポルトラ } \\
\text { ンドセメント }(\mathrm{m} 3 / \text { 個 })\end{array}$ & 0.454 & 0.445 & 0.436 & 0.423 & 0.438 & 0.400 \\
\hline $\begin{array}{l}\text { 鉄筋·普通鋼小棒 } \\
\text { (kg/值) }\end{array}$ & 3.91 & - & - & - & - & - \\
\hline \begin{tabular}{|l} 
型挅(kg/個) \\
$※ 30$ 回転用を想定
\end{tabular} & 169 & 268 & 245 & 253 & 222 & 216 \\
\hline
\end{tabular}

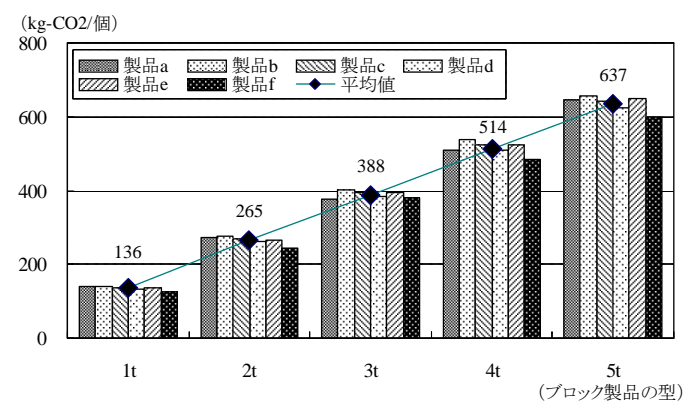

図-5 異なる根固ブロック製品の製造時における $\mathrm{CO}_{2}$ 排出量 
階における $\mathrm{CO}_{2}$ 排出量の差異は平均值に対して1割未満 で，これはいずれの型（1～5t）についても同様であっ た. このため所定の性能を有する限りでは, 当初予定さ れている製品に替えて別の製品を使用したとしても $\mathrm{CO}_{2}$ 排出量の大幅な低減は見込めないこととなる.

次にこれらコンクリート・ブロック製品として，高炉 スラグなどを用いた製品を使用した場合の $\mathrm{CO}_{2}$ 排出量低 減効果について検討寸る。このような製品の製造段階に おける $\mathrm{CO}_{2}$ 排出量に関しては, 曽根ら(2010)が高炉セメ ントやフライアッシュセメントの $\mathrm{CO}_{2}$ 排出量原単位を作 成している9．その結果によれば，コンクリート・ブロ ック製品の製造に通常使用されてきたポルトランドセメ ントの $\mathrm{CO}_{2}$ 排出量原単位は7.4×102 $\mathrm{kg}-\mathrm{CO}_{2} / \mathrm{t}$ であるのに対 し, フライアッシュセメントは $6.1 \times 10^{2} \mathrm{~kg}-\mathrm{CO}_{2} / \mathrm{t}$, 高炉セ メントは $4.4 \times 10^{2} \mathrm{~kg}-\mathrm{CO}_{2} / \mathrm{t}$ であり, ポルトランドセメント

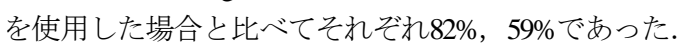
このため河川の護岸・根固として高炉セメントを用いた 製品を使用寸ることで，資材の製造による $\mathrm{CO}_{2}$ 排出量を 最大6割程度にまで低減させることが可能となる.

また上記以外の取り組みによって $\mathrm{CO}_{2}$ 排出量がどの程 度低減されるかについて, 工事実施による $\mathrm{CO}_{2}$ の排出は, 建設機械の製造・稼動によるものと資材の製造・運搬に よるものとがある．資材の製造段階での $\mathrm{CO}_{2}$ 排出量の低 減方策は先に検討した通りである. 資材の運搬について は, 資材の調達先との距離によるもので, 実際の工事で は椂々な工夫が期待されるものの, 低減シナリオとして 運搬距離の低減を想定することはできない，また建設機 械の製造による $\mathrm{CO}_{2}$ 排出量は，これまでの試算手法によ れば建設機械重量に, 機械重量当たりの $\mathrm{CO}_{2}$ 排出量原単 位を乗じ，それと機械の減価償却分を考慮して算定され る. そして減価償却分は建設機械の実際の稼働時間から 算定されるため，機械の標準的な性能によれば施工対象 とする土砂や資材の数量から自ずと導き出せることとな る. 同様に建設機械の稼動による $\mathrm{CO}_{2}$ 排出量についても, 標準的な性能や燃費によれば資材の数量から導き出せる. このため標準仕様に基づく限り，建設機械の製造・稼動 段階での $\mathrm{CO}_{2}$ 排出量は施工対象とする土砂や資材の数量 から算定され，それらの数量が変わらない限り $\mathrm{CO}_{2}$ 排出 量の低減を見込むことはできない，ただし，これは環境 負荷低減に向けてどのような方策が考えられ，そのシナ リオへの適用可能性を検討寸るものであり, 実際の工事 では例えば建設機械の燃費改善や工程の短縮, 省エネ・ 省力化など各施工会社の創意工夫によって様々な低減方 策が考えられる．このため，ここで低減シナリオとして 想定されていないからといって, 実際の施工に際しその ような工夫を妨げようとするものではない.

以上により，低減シナリオ II では $\mathrm{CO}_{2}$ 排出量の約4割 低減が見込まれる高炉セメントによるコンクリート・ブ
ロック製品を用いて環境負荷の算定を行った.

\section{（3）環境負荷量の算定と低減効果の分析}

以上の条件設定からべースラインシナリオ及び低減シ ナリオ I， IIによる環境負荷量をそれぞれ算定した（表 -3）。ベースラインシナリオでは $\mathrm{CO}_{2}$ 排出量が2,551t$\mathrm{CO}_{2}$ であったのに対し，低減シナリオ I では $1,648 \mathrm{t}-\mathrm{CO}_{2}$

（35\%の低減），低減シナリオ II では $1,233 \mathrm{t}-\mathrm{CO}_{2}$ （52\%の 低減）であった。この結果から土砂等の再利用による $\mathrm{CO}_{2}$ 排出量の低減効果は大きく, またコンクリート・ブ ロック製品に高炉セメントを用いた低減シナリオIIでは 低減シナリオ I に比べて $25 \%$ 程度低減された。

次に $\mathrm{CO}_{2}$ の排出と廃棄物の双方を考慮した環境負荷の 低減効果について検討を行う。ベースラインシナリオで は工事で発生する残土・廃姤をすべて処分場に運搬して 処理することとしており, その発生量として残土822t, コンクリート殸183t，アスファルト殸200tなどであった この廃棄物発生量と $\mathrm{CO}_{2}$ 排出量を共通の指標によって評 価するため, LIME2の統合化係数を用いて比較を行った. この結果, $\mathrm{CO}_{2}$ の排出と廃葉物の発生双方を考慮した場 合, ベースラインシナリオに対して低減シナリオ I, II では被害額がそれぞれ16\%，12\%にまで低減された。

これらの結果から, 各低減シナリオに示寸方策を講じ ることで環境負荷が大幅に低減される.このため工事の 実施に当たっては比較的近距離から土砂等を受け入れて 再利用寸ることが重要であり, それは当該工事から発生 寸る不要物の受け入れ先確保についても同様である. ま た高炉セメントを用いた製品を使用する場合でも環境負 荷の低減が期待されるが，そのような製品については， 現時点で大量供給・実用化が十分に進んでいるとは言い がたい状況にある. 今後はこれら製品の普及・流通が進 み, また他のリサイクル製品についても技術開発を通じ て実用化・普及されることを期待したい.

表-3 ベースラインシナリオ及び各低減シナリオによる 環境負荷量と被害額の比較

\begin{tabular}{|c|c|c|c|}
\hline & К゚ースラインシナリオ & 低咸シナリオ I & 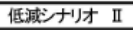 \\
\hline CO2排出量 & $2.551 \mathrm{t}-\mathrm{CO} 2$ & $1,648 \mathrm{t}-\mathrm{CO2}$ & $1.233 \mathrm{t}-\mathrm{CO2}$ \\
\hline うち、建設機诚の製造段制 & $34 \mathrm{t}-\mathrm{CO} 2$ & $34 \mathrm{t}-\mathrm{CO} 2$ & $34 \mathrm{t}-\infty \mathrm{2} 2$ \\
\hline うち、建設機械の稼俅段階 & $191 \mathrm{t}-\mathrm{CO} 2$ & $191 \mathrm{t}-\mathrm{CO}_{2}$ & $191 \mathrm{t}-\infty \mathrm{2}$ \\
\hline うち、資材の製造段階 & $1,832 t-\mathrm{CO} 2$ & $1,256 \mathrm{t}-\mathrm{CO2}$ & $841 \mathrm{t}-\mathrm{CO} 2$ \\
\hline うち、資材の運搬段階 & $494 \mathrm{t}-\mathrm{CO} 2$ & $167 \mathrm{t}-\mathrm{CO2}$ & $167 \mathrm{t}-\mathrm{CO2}$ \\
\hline 地球温暖化被崈額(※1) & 5,944 千円 & 3.840 千円 & 2,874 千円 \\
\hline 残土発生量 & $822 \mathrm{t}$ & $0 \mathrm{t}$ & $0 \mathrm{t}$ \\
\hline 㢅棄物(残土)発生被害額(※2) & 11,913 千円 & 0 千円 & 0 千円 \\
\hline 碚石・コンクリート祋等の発生量 & $415 \mathrm{t}$ & $0 \mathrm{t}$ & $0 \mathrm{t}$ \\
\hline 廃童物 (砕石等) 発生被害額(※3) & 5,645 千円 & 0 千円 & 0 千円 \\
\hline \begin{tabular}{|c|} 
被害額の合計 \\
\end{tabular} & 23,501 千円 & 3.840 千円 & 2,874 千円 \\
\hline 割合 & $100 \%$ & $16 \%$ & $12 \%$ \\
\hline
\end{tabular}

※1 地球昷暖化統合化係数しして, LME2より2.33円 $/ \mathrm{kg}-\mathrm{CO} 2$ を使用。

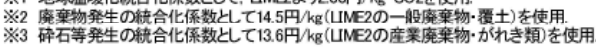




\section{4. 環境負荷低減を意図した河道設計・施工の検 討手順の構築}

河川改修を行おうとする場合は，現沉河道の課題や周 辺地域の状況を把握し，図-6・左側の流れに示寸ように まずは計画流量・水位や改修区間などの基本諸元を設定 する ${ }^{10)}$. そして複数の河道己焂案を想定して事業費や用 地面積をそれぞれ算定して比較検討が行われ，治水・利 水・環境への効果及び影響について総合的な評価が行わ れて最終案が決定される. 現在適用されている検討手法 では，良好な河川環境の整備・保全等を十分に考慮した 措置を講じることとされているが，広域的・長期的な環 境影響までを考慮するものとはなっていない，今後の河 道設計や施工に当たっては，河川環境の直接的な影響だ けでなく, 地球温暖化や廃棄物といった環境影響にも配 慮した検討が必要となってくる．このため，図-6・右側 の流れに示寸ように，河道設計から施工までの全体の流 れの中での環境負荷低減を意図した検討手順を構築・提 案することとしたい.この手順は，複数の河道改修案に ついて事業費だけでなく $\mathrm{CO}_{2}$ 排出量や廃棄物発生量とい った環境負荷量の算定を行い，それらをあわせ勘案して 最終案を決定するものである. このとき設計段階で環境 負荷の比較検討を行う際に, 他の工事から土砂やコンク リート等を再利用できるかどうかによって評価が変わっ てくる可能性がある.このため設計段階で最終案を決定 しょうとする場合, 近隣で予定されている工事と当該工 事とで実施予定時期の調整を図るとともに，残土や廃款 の調達や受け入れ可能性について予め検討しておく必要 がある。

そのような設計段階での土砂等の再利用を想定しつつ, 施工段階においてはその実現を図るとともに，護岸など の資材としてリサイクル材を使用寸ることによっても環

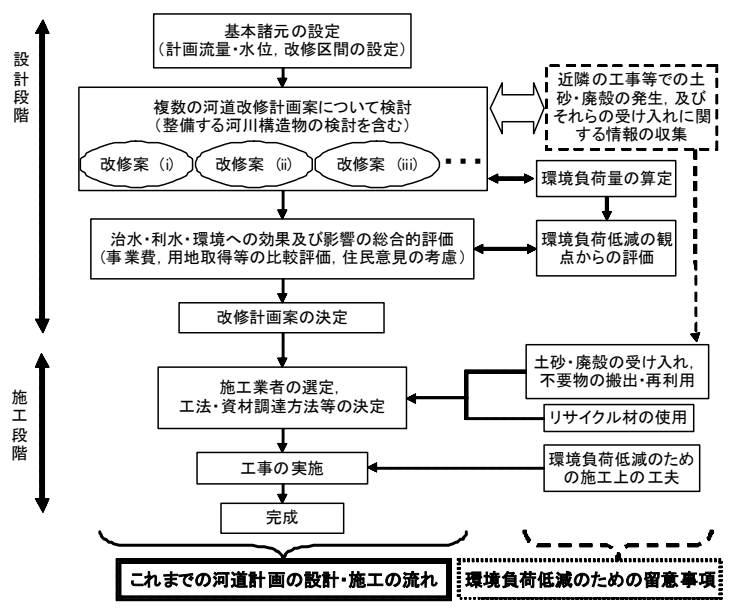

図-6 環境負荷低減を意図した河道設計・施工の検討手順
境負荷の低減が図られる，そして実際の施工に当たって は燃費の良い建設機械を使用することや工事の合理化・ 効率化など施工上の工夫を講じることで更なる負荷の低 減が期待される.

\section{5. まとめ}

本稿では実際の河川工事を対象として，設計段階で複 数の河道改修案を想定し, それぞれについて事業費や $\mathrm{CO}_{2}$ 排出量, 廃棄物発生量といった環境負荷量を算定し た. またLIME2の統合化係数を用いて比較検討を行い, 各案の実現可能性を考察した. また施工段階について, 資材を新たに採取・製造して廃棄物を運搬・処理する心゙ 一スラインシナリオに対し, 残土等の再利用やリサイク ル材を使用する低減シナリオを設定し，各シナリオで講 じられる環境負荷低減方策の効果を分析した．さらに現 在の河道設計・施工の検討に当たっては $\mathrm{CO}_{2}$ の排出や廃 棄物の発生など広域的・長期的な環境影響が十分考慮さ れていないことから，今回の検討結果を踏まえ，環境負 荷低減を意図した河道設計・施工の検討手順を構築した。

河川工事などの社会資本整備分野では， $\mathrm{CO}_{2}$ 排出量や 廃棄物発生量の抑制が今後ますます求められるものと予 想される. その一方で，これら環境負荷量を算定し，そ の定量評価を行う手法は未だ十分に確立されていない. また設計・施工の各段階では取り扱う情報は異なり，実 施主体も異なる場合があることから，設計から施工まで の一連の流れを見通して環境負荷の低減に取り組む必要 がある.ここで提示した環境負荷低減方策や河道設計・ 施工の検討手順が全国の河川管理者や建設コンサルタン ト・施工会社に広く参照されることで，環境負荷低減に 向けた取り組みが一層推進されることを期待したい.

謝辞 : 本研究は土木学会環境システム委員会に設置され た社会資本LCAに係る各委員会での議論から有用な示唆 をいただいた，論文の全体構成について和歌山工業高等 専門学校の霍巻峰夫教授に助言をいただいた。 また環境 負荷量の算定など八千代エンジニヤリング株式会社に協 カいただいた.ここに深く感謝申し上げる.

\section{参考文献}

1）島谷幸宏・小野和憲・萱場祐一：自然を活かした川 づくりによる $\mathrm{CO}_{2}$ 排出量の削減，土木技術資料 Vol.40, No.6, pp.56-61, 1998.

2) 池田鉄哉・天野邦彦・岸田弘之: 河川工事による $\mathrm{CO}_{2}$ 排出量の試算とライフサイクルアセスメント手法の適用 に係る基礎的考察，土木学会環境システム研究論文集 
Vol.38, pp.193-202, 2010.

3) 山田聡宣・島谷幸宏・末松吉生 : 中小河川の改修手 法の工夫による $\mathrm{CO}_{2}$ 排出量の削減，土木学会河川技術論 文集 Vol.16，pp.455-458，2010.

4) 独立行政法人国立環境研究所地球環境研究センタ 一：産業連関表による環境負荷原単位データブック (3EID), 2002.

http://www-

cger.nies.go.jp/publication/D031/jpn/page/data_file.htm (平成 22 年 3 月 11 日取得)

5) 国土交通省：中小河川に関寸る河道計画の技術基準 について, 2010.

http://www.mlit.go.jp/river/kankyo/main/kankyou/tashizen /pdf/gijyutsukijyun.pdf (平成 23 年 2 月 23 日取得)

6) 伊坪徳宏・稲葉敦編 : LIME2 一意思決定を支援する環境影 響評価手法，社団法人産業環境管理協会，2010.

7) 共和コンクリート工業株式会社 : 根固・護床工製品 ホームページ, 2011. http://www.kyowa-concrete.co.jp/seihin/negatame.html (平成 23 年 2 月 23 日取得)

8）日建工学株式会社：3 連ブロック製品ホームページ, 2011.

http://www.nikken-

kogaku.co.jp/products/product/product_36.html (平成 23 年 2 月 23 日取得)

9) 曽根真理 - 瀧本真理 - 岸田弘之・藤田壮 : 社会資本 LCA に用いるインベントリ・データ・ベースの開発, 土木学会第 65 回年次学術講演会講演概要集VIII-083, pp.165-166, 2010.

10）国土交通省河川局：国土交通省河川砂防技術基準 同解説・計画編, 社団法人日本河川協会編・発行, 山海堂, pp.125-126, 2005.

(2011.8.18 受付)

\title{
STUDY ON THE REDUCTION MEASURES OF ENVIRONMENTAL LOADS AT THE DESIGNING AND CONSTRUCTION STAGES OF THE RIVER WORKS
}

\author{
Tetsuya IKEDA, Kunihiko AMANO and Hiroyuki KISHIDA
}

In the field of infrastructure construction including river works, construction materials such as concrete are used, and it needs to transport them for the long distance. Due to recent growth of public awareness on the environmental issues, it becomes more important to estimate and reduce the environmental loads brought by the infrastructure construction. In the infrastructure construction, it is necessary to take notice of carbon dioxide and waste materials as the broad-based and long-range environmental loads. On the other hand, it is necessary to conduct the quantitative evaluation on these environmental loads and to investigate the reduction measures by considering the actual situation of construction. Focusing on the river works, this paper estimates the cost of construction, the carbon dioxide emission and final disposal volume on the several alternative plans at the designing stage, compares the significance of different environmental loads by using the integrated factors of LIME2, and analyzes the effectiveness of reduction measures. It also establishes the reduction scenarios of the environmental loads, and analyzes the effectiveness compared to the base-line scenario in which the materials are newly extracted and produced. Based on the results, it establishes the procedure intending to reduce the environmental loads at the time of river planning and construction, which will be referentialized by river managers, construction consultants and constructors nationwide. 